one million pounds worth of goods from England, and exports about $\mathbf{1 . 2 5}$ millions in value.

The development of the oases of the south have opened up the desert, so to speak, to regular exploitation. Owing to lack of water, this policy of development has to be slow. But the results already obtained between Touggourt and Biskra, along the Oued R'ir, are most promising. The co-operation of the local proprietors, such as the Cheikh El-Arab ben Gana, who is the head of all the Arabs of North Africa, is an invaluable asset for the progress of the country. As things stand at present, there are most interesting comparisons to make from this point of view, with the methods used in Irak, Egypt and Libya for the exploitation of the desert belt of North Africa and Asia Minor.

Algeria is of great importance for the historian and the geographer. The imposing ruins of Timgad and Djemila ${ }^{3}$ are an epitome of Roman history, and a testimony to the genius and power of Rome ${ }^{4}$; while Islamic civilization has left lasting marks throughout this rich land ${ }^{5}$. A curious experience is offered by the M'zab country, the home of the Puritans of Islam, who fled right into the desert to escape the persecutions of the orthodox Moslems, and founded there the interesting towns of Ghardaia and Guerrera and other villages, where they keep intact their religious laws and customs ${ }^{6}$.

Then there is the unique experience offered by the Sahara, which is now open to regular traffic from one end to the other". The geography, geology, flora and fauna of this vast tract of land are now objects of systematic study. Among the most notable achievements of French scholars in this field of research are the results obtained by Prof. Reygasse, head of the Anthropological Museum of Algiers, during his expeditions in the fastnesses of the Hoggar, the land of the Tuaregs. There he discovered distinct signs of a primitive civilization, which was mentioned by Herodotus. The carvings and rock paintings, some of them twenty feet high, which he discovered in the Hoggar mountains, that rise to more than 8,000 feet, areamong the most precious specimens of primart.

T. GreEnwood.

1 "Algérie 1937". By various authors. Pp. 184.

2 "Pour comprendre l'Algérie". By René Lespès. Pp. 219. (1937).

3 "Djemila". By Louis Leschi. Pp. 40. (1938.)

4"L'Afrique Romaine". By Eugène Albertini. Pp. 70. (1937.)

5 "L'Algérie Terre d'Art et d'Histoire". By A. Berque. Pp. 369. (1937.)

"Ghardaia la Mystérieuse". By Marcel Mercier. Pp. 391. (Algiers Soubiron, 1932.)

7"Le Sahara Algérien". By Léon Lehuraux. Pp. 64. (1937) (Algiers : Gouvernement Général de l'Algérie.)

\title{
Future Developments in Coal Treatment and Utilization
}

$\mathrm{T}$ THE future of coal is of interest in some form or another to modern industries of all kinds, but is of special interest to the technicians and industrialists of the Tyneside area. This gave special importance to the symposium on "Future Developments in Coal Treatment and Utilization" arranged by the New. castle-on-Tyne Section of the Society of Chemical Industry at King's College, Newcastle-on-Tyne, on December 7 last. The papers dealt with quite different aspects of fuel technology, and the change of point of view of the speakers was stimulating where a similar series of papers all on the same lines might have been tiring.

The papers by Dr. W. T. K. Braunholtz and by Dr. E. W. Smith can be considered together. The first was a careful survey of the growth of research in the gas industry from the early days of individual effort to the organized research of to-day which embraces all subjects of interest to the industry, from retort refractories to ammonia recovery. The organized work of to-day is in the hands of the Institution of Gas Engineers and of the collaborating organizations. Dr. Braunholtz directed attention to the important effect of former researches and hinted that the future might witness remarkable advantages in the technology of gas production. He was referring, no doubt, to the Institution's researches at the University of Leeds on the complete gasification of coal or coke with hydrogen under pressure. $\mathrm{He}$ visualized a future in which our domestic fuels will all be fluid, stating that the open grate must even. tually disappear. Although Dr. Braunholtz may be right, it must be said that, at the moment, the development of smokeless fuels is actually stimulating interest in the open grate.
Dr. E. W. Smith took up the story where Dr. Braunholtz left off, but treated the subject more from the economic point of view. He started by postulating the importance of administration, witl.out which research cannot properly serve its intended purpose. Dr. Smith considers that there will be no radical change in the technique of carbonization either in the coking or gas industries for some time, although a steady evolutionary advance will be made in matters of detail. $\mathrm{He}$ considers that the future tendency of the carbonizing industries will be towards increasing flexibility, and pointed out that an all-gas policy does not make for overall efficjency. He prefers that flexibility which is derived from a, variety of products, and as one example in gas manufacture pointed out that the yield of coke for sale could be increased by as much as 143 per cent if coal gas were used for retort heating so as to liberate coke for sale. This very great potential increase in the production of coke has seldom been realized.

As regards the relations of the two industries, it is obvious that even closer co-operation should be brought about in order to utilize properly the cokeproducing capacity of coke-oven plants, when metallurgical coke is not being made, and the capacity in the gas industry, and also to overcome the difficulty of discontinuity in the supply of coke-oven gas to other industries.

The paper by Dr. J. G. King struck an entirely different note. Pointing out that the properties of coals are still not fully known, the author gave a variety of examples to show where a greater knowledge of these properties may not only influence the preparation of coal for the market and its use in 
existing industries, but may also indicate new markets. Thus a study of the physical structure of coal can give assistance in coal mining and coal breaking problems, in the dedusting of fine coal and in coal cleaning. It has already been shown that the nature and extent of the bands, partings and cracks in lump coal can be examined radiographically before and after the adsorption of lead salts, and that a study of microstructure can aid in the selection of coals for the production of active carbons in which the original structure of the coal is retained.

Dr. King pointed out the importance of the changes which occur in coal on heating, to the carbonization and other industries, and admitted that we are still very ignorant of the true meaning of these changes. A greater knowledge, he said, would greatly help coal blending and the precise selection of coals for special purposes such as complete gasification and the motor-lorry gas producer. Although research on the chemical constitution of coal has not yet achieved its object, Dr. King feels that new lines of attack should be tried; previous work has already indicated new processes such as the production of ash-free coke by the Pott-Broche process and the production of base-exchange agents by the action of sulphuric acid. The paper stimulated a lively discussion in which many and diverse points were touched upon. It seemed to be generally agreed that the proper utilization of coals would be furthered by the close definition of their fundamental properties.

The paper sponsored by Prof. A. C. G. Egerton detailed one important aspect of the properties of coal, namely the part played by its sulphur content. Since the utilization of high-sulphur coals may be one of our future problems, it is desirable to know now how the sulphur can be controlled. Mr. Armstrong (research student from South Africa) detailed experiments on the partial elimination of sulphur from coke by passing various gases through the coal during carbonization in the presence of inorganic substances. The reductions are quite marked in some cases with steam, hydrogen or ammonia; but inert gases have little effect.

The sulphur problem attracted some discussion from the steel technologists present, it being pointed out that a decrease of 0.1 per cent in the sulphur of coke would represent a saving of 18. per ton in the cost of pig iron.

On account of the high cost involved, the production of motor-spirit and oil from coal has not greatly increased in Great Britain, but considerable strides have been made in the technical sphere. Dr. R. Holroyd described some of the important advances which Imperial Chemical Industries Ltd. have made in connexion with the control of the chemical composition and octane number of the motor-spirit. Three types of catalyst are now available for the vapour-phase stage of the process so that cracking, hydrogenation and isomerization reactions can be controlled to give motor-spirit of the composition necessary for high knock rating. Thus spirit can be made with a very high aromatic and low normalparaffin content; this has a high octane number (80) but a low susceptibility to lead tetraethyl (4 ml. per gall. raises the octane number to 86-7). Alternatively, spirit rich in branched-chain paraffins and lowboiling naphthenes can be made; this has a lower octane number (75-6) but a much higher susceptibility to lead tetraethyl, since $4 \mathrm{ml}$. per gallon raises the octane number to 89-90. Dr. Holroyd said that when similar control has been established over the liquid-phase stage the hydrogenation process will have more control over its products than the oil industry.

Although not the last paper of the evening, Captain J. G. Bennett's paper really constituted a final word on coal utilization. By assessing the items influenced by the type of fuel, such as overheads, maintenances, repairs, etc., he was able to demonstrate mathematical relationships between the "figures of merit" for fuels, these figures of merit being technical efficiency, economic efficiency and psychological merit. For the three types of energy, coal, gas and electricity, a ternary diagram may be constructed. Although his proposals are still not fully developed, Captain Bennett was able to show how this diagram can be used for the analysis of statistical and operating data referring to fuel problems; the trends in costs can be followed and the appropriate fuel chosen for any particular purpose. The proposals attracted considerable interest, although it was thought that the large number of variables would make the calculation difficult and might impair accuracy.

\section{Scientific Research and Industrial Needs in Canada}

N a recent address to the Canadian Chamber of
Commerce, Major-General A. G. L. McNaughton
dealt with those activities of the National Research
Council that serve to enlarge the demands of industry
for the produce of farms, fields and factories. At
present, Canadian industry draws about 12 per cent
by value of its raw materials from agriculture, or
about one third, if forests be included. He referred
to recent progress in the United States, where four
large research institutes, each endowed with an
annual revenue of a million dollars, have been estab-
lished; and he laid special stress upon German
progress in the same direction under the four-year
plan. Whereas about 45 per cent of the annual cut
of wood was formerly used for low-grade fuel, now
95 per cent is consumed by industry, and Germany is
striving to replace iron and steel for construction work by synthetic resins derived from wood and agricultural products. If Canada is to survive, said General MeNaughton, she must follow the same path, for the old-time one-product system of farming is becoming unremunerative in view of the growth of national self-sufficiency in Europe.

At the same meeting, Dr. C. Y. Hopkins outlined some of the chemical problems now being studied in Canada with the above object in view. China wood oil has of late been replacing linseed oil in varnishes and enamels, and the production of flax-seed in Canada has much diminished; hence efforts are being made to find a satisfactory alternative either by chemical modification of China wood oil or by breed. ing a new variety of oil-eeed that could be cultivated in Canada. A home-grown substitute for the vegetable oils now largely imported for soap-making is also 